\title{
Reproductive Strategy, Performance, and Population Dynamics of the Introduced Weed Black Henbane (Hyoscyamus niger)
}

\begin{abstract}
Christa E. Fettig, and Ruth A. Hufbauer*
Determining whether and how to manage an introduced species requires basic ecological and biological knowledge. If a decision is made to actively manage an invader, doing so efficiently and effectively is critical. Basic biological or ecological information can be key in designing effective and cost-efficient management approaches. We used a greenhouse experiment and observational field studies of naturalized populations to study the modes of pollination, fecundity in the field, seed ecology, population dynamics, and demography of the introduced and toxic weed, black henbane. We showed that henbane was able to self-pollinate. Furthermore, outcrossing did not increase number or size of seeds. Plants in the sampled populations produced an estimated average of $25,300 \pm 4,004$ seeds by the middle of the growing season. We found no difference in the viability of field-collected seeds that were 1 to $4 \mathrm{yr}$ old. The number of flowering plants in a population was best predicted by the number of rosettes at that location in July of the previous year. The probability of rosettes surviving over the winter to reach reproductive maturity increased with precipitation and growing degree days. Total population sizes fluctuated dramatically between years. Henbane populations are ephemeral, but with large seed banks, outbreaks are possible if conditions are right. Given that this weed is toxic to livestock and humans, it is important to identify infestations and manage populations.
\end{abstract}

Nomenclature: Black henbane, Hyoscyamus niger L. HSYNI.

Key words: Invasion, seed bank, demography.

Biological invasions are one of the top threats to biodiversity and global environmental sustainability (Mack and D'Antonio 1998; Pimentel et al. 2000). Worldwide, approximately $80 \%$ of all threatened and endangered species are on the protected list because of the influence and effects of nonnative species (Wilcove et al. 1998). In the United States alone, the cost of managing invasive species and direct revenue loss due to invasion add up to a staggering $\$ 120$ billion per year (Pimentel et al. 2005). Not all introduced species have extreme impacts in their new range and thus not all require management. To determine both whether and how to manage these species requires basic biological and ecological knowledge.

If a decision is made to actively manage an invader, doing so efficiently and effectively is critical. Basic biological or ecological information can be key in designing effective and cost-efficient management

DOI: 10.1614/WS-D-16-00034.1

*First and second authors: Graduate Student and Professor, Graduate Degree Program in Ecology, Department of Bioagricultural Sciences and Pest Management, Colorado State University, Fort Collins, CO 80523. Corresponding author's E-mail: christafettig@gmail.com approaches. For example, successful eradication of the giant African snail (Achatina fulica Bowdich) from Florida was achieved for the relatively low cost of $\$ 1$ million (Capinera 2014). Simberloff (2003) argues that an important biological factor was essential to this eradication effort: the snail is selfincompatible. This made eradication feasible, as the population had only to be reduced to the point where individuals had difficulty finding mates. Another example of the role of basic ecological information in successful management comes from the eradication of kochia [Kochia scoparia (L.) Schrad.] from more than 3,200 ha of western Australia (Randall 2001). In this case, the knowledge that kochia has a limited seed bank life of less than 3 yr (Zorner et al. 1984) was instrumental in planning the eradication process of previously known locations: sites had to be managed for a minimum of $3 \mathrm{yr}$ after the last seeds had set. In each of these examples, it was important to understand fundamental aspects of the biology of the system.

The questions of whether and how to manage an introduced species depends, at least in part, on population dynamics. If populations of a well-established invader (beyond the point at which eradication might be feasible) are growing and becoming more dense, 
they might warrant management to reduce further spread and minimize ecological effects on local habitats. However, if populations are not consistently growing, then management efforts could perhaps be better focused on introduced species of higher concern. Knowledge of the underlying factors that can drive plant population size fluctuations (e.g., reproductive strategy and capacity, seed bank capacity and seed longevity, plant demographics within populations) and how unmanaged populations persist over time need to be considered when creating management programs.

Whether one is trying to determine the level of threat that an introduced species poses or working toward eradication of a known, problematic invader, basic ecological information is necessary. However, even for some species introduced centuries ago, basic information is lacking. One such species is black henbane.

Black henbane is a monocarpic annual or biennial weed that was introduced in the early 1600 s to North America from Eurasia. The specific source of black henbane is not known. It is not a problematic weed in its native range and is, in fact, rather difficult to find (CEF and RAH, personal observations). Originally planted and used as a medicinal and ornamental plant, black henbane escaped cultivation and is now found throughout much of the United States and Canada (U.S. Department of Agriculture [USDA] PLANTS database 2015). It is toxic to the point of causing livestock and human poisoning and death (Cooper and Johnson 1984; Couch 1937; Kurkcuoglu 1970; Lindequist 1993; Long 1924; Spoerke et al. 1987). Despite its toxicity and the fact that it has been in North America for centuries, remarkably little is known about its ecology (Selleck 1964). Only two papers about the ecology of black henbane have been published since Selleck's work in 1964 (Fettig and Hufbauer 2014; LaFantasie and Enloe 2011). Black henbane is widespread across multiple western U.S. states and is successful at colonizing disturbed habitats. In Colorado, Wyoming, and Montana black henbane is managed as one of several invasive species of concern. Individual states have lists of noxious weeds that they target and manage. In the western United States control of henbane populations is managed by weed supervisors at the state and county levels, ranchers and private landowners, public agencies (e.g., Bureau of Land Management, USDA), and energy companies. Plants are managed in pasture lands and hay fields due to the plant's toxicity and threat to livestock, but efforts are also made to manage populations found elsewhere (e.g., public lands, disturbed areas such as pipeline rights-of-way, and roadsides). More information about the biology of this introduced species will provide insight into the ecology of its invasion, will help determine whether management efforts are warranted, and will provide the foundation upon which sound management approaches can be developed.

To understand the ecology of introduced populations of black henbane we address the following five topics and motivating sets of questions using a combination of experimental and observational studies.

1. Reproduction: Is black henbane capable of selfpollination? Does it benefit from outcrossing with plants from within the same population or from other populations?

2. Field performance: Are there differences in plant size by location? Does climate or location influence differences in plant size? How much seed do plants in introduced populations produce? Are there key climatological variables driving seed production?

3. Seed ecology: How large are soil seed banks? Do seeds remain viable multiple years?

4. Population dynamics: How large are introduced populations? Are there consistent trends in population size (i.e., growth or decline)?

5. Demography: When does mortality occur between rosette and adult? What proportion of rosettes reach adulthood? Is survival probability shaped by the immediate surroundings of a rosette?

By answering the above questions, our overarching goals are to understand basic biological and ecological characteristics of black henbane in the introduced range, to lay the groundwork for additional ecological and evolutionary research on this species, and to help guide sound management practices.

Study System. Black henbane was introduced to eastern North America in the 1600s and is now found in 27 northern states and throughout much of Canada (USDA PLANTS database 2015). As of 2015, black henbane is a state-listed noxious weed in California, Colorado, Idaho, Nevada, New Mexico, and Washington (USDA PLANTS database 2015). County weed supervisors in Wyoming are petitioning for black henbane to be placed on their state noxious weed list as well (CEF, personal observation). Black henbane is also listed on the 
Bureau of Land Management National List of Invasive Weed Species of Concern (USDA National Invasive Species Information Center 2016).

Black henbane was initially introduced to North America by early settlers as an ornamental plant and medicinal herb. A high concentration of scopolamine, hyoscyamine, and other tropane alkaloids made black henbane an effective treatment for toothaches, asthma, rheumatism, and stomach pains, and it was also used as a general anesthetic in early medicine around the world (Biswas 1956; Husain et al. 1979; Rätsch 1995; Rowell 1978). However, those same compounds, which are found in all parts of the plant, make it highly poisonous if improperly used. Human poisoning and death following black henbane consumption has been reported in many areas of the world. For example, 31 cases of black henbane poisoning in children were reported in Turkey over the course of 3 yr (Kurkcuoglu 1970). However, the total number of henbane poisonings in that region was thought to be much greater, because the vast majority of the poisonings occurred in remote villages and children died on the journey to the nearest hospital (Kurkcuoglu 1970). Spoerke et al. (1987) reported the accidental ingestion and poisoning of two people in Montana, when henbane growing on their property was mistaken for parsnip. Symptoms included vomiting and disorientation in the $11 \mathrm{~h}$ following ingestion, but both subjects ultimately recovered (Spoerke et al. 1987). A number of other studies have also reported instances of henbane ingestion and poisoning (Beasley 1999; Doneray et al. 2007; Knight and Walter 2003; Long 1924; Sands and Sands 1976) or have focused on the toxicity of the plant (Häkkinen et al. 2005; Lindequist 1993; Ma et al. 1999).

Little ecological information on black henbane has been published to date. Black henbane is a monocarpic plant with both annual and biennial forms in the native range (Correns 1904; Selleck 1964). It is the biennial form that composes populations in North America (Fettig and Hufbauer 2014). Biennial plants grow as a rosette during the first growing season. After experiencing cold winter conditions the plants bolt, flower, set seed, and die the following growing season. A requirement for vernalization likely limits North American plants to the northern states and Canada (Fettig and Hufbauer 2014). Black henbane has been reported to grow between 0.3 and $0.9 \mathrm{~m}$ tall and produce tens of thousands of seeds per plant (Whitson et al. 2004). Seeds are scattered locally via gravity and are typically spread to a new location via human activity (e.g., truck tires, movement of soil, etc.). It has not been reported how long seeds are viable in the seed bank. Plants typically grow in disturbed areas and are poor competitors (LaFantasie and Enloe 2011).

\section{Materials and Methods}

Reproduction. To evaluate the degree to which introduced henbane is self-compatible and whether interpopulation outcrossing improves seed set or germination, we conducted two experiments in which we manipulated pollination in the greenhouse. In the first, we simply evaluated whether self-pollination is possible, using two treatments: self-pollination with no manipulation and self-pollination by hand. In the second experiment we evaluated the effects on seed set of three treatments: a cross with a sibling, a cross with an individual from the same population, and a cross with an individual from a different population.

Seed was collected from two introduced populations (one population in Colorado and one population in Montana) in the fall of 2009. The term "introduced populations" refers to naturalized plant populations in the introduced range. Seeds were stored in a refrigerator at $3.4 \mathrm{C}$ until planting. Seeds were planted in germination flats with Fafard brand "Lightweight Mix" potting media (containing $55 \%$ sphagnum peat moss, $20 \%$ perlite, and $25 \%$ vermiculite; Sun Gro Horticulture, 770 Silver Street, Agawam, MA 01001) and placed on a mist bench with a misting regime of $15 \mathrm{~s}$ duration every $3 \mathrm{~min}$ for $9 \mathrm{~h} \mathrm{~d}^{-1}$ over $12 \mathrm{wk}$. The median date of germination was 6 wk after sowing. Seven weeks after germination the seedlings were transplanted to $4 \mathrm{~L}$ pots and kept in a greenhouse with a 16/8 h day/night photoperiod and 25/17 C day/night average temperatures until flowering. We used 15 plants from each of the two populations for the experiments.

For each cross, a vented polyethylene bag was secured over newly opened flowers to reduce the possibility of pollen contamination. For the first experiment, in which plants were self-pollinated, anthers were left intact, while for each of the outcrossed treatments, anthers were removed prior to opening, in an effort to ensure that successful pollination was due to our experimental manipulations rather than self-fertilization.

Following our controlled crosses, the seed capsules were harvested once they were fully brown and mature on the stalk. We collected the seeds from each capsule, weighed them, counted a subsample of 20 seeds, and stored them in a refrigerator at $3.4 \mathrm{C}$ for $20 \mathrm{wk}$. 
To evaluate germination success, 10 capsules from each cross were randomly selected (five capsules from maternal plants from Colorado and five capsules from maternal plants from Montana) for the experiment. We placed two replicates of 50 seeds per capsule on moist filter paper in petri dishes. The dishes were kept in a germination chamber set to a $14 / 10 \mathrm{~h}$ day/night photoperiod and at an average temperature of $20 \mathrm{C}$. We ended the experiment after $47 \mathrm{~d}$, at which point germination rate across all dishes had greatly decreased and $3 \mathrm{~d}$ had passed with no germination at all.

All statistical procedures in this publication were carried out using $\mathrm{SAS}^{\circledR}$ software version 9.3 (Sas Institute, 100 SAS Campus Drive, Cary, NC 27513). We used mixed linear models as implemented in the SAS (PROC MIXED) to evaluate the difference in seed production, seed weight, and germination rates between naturally selfed and selfed by hand crosses and between different crosses with different levels of outcrossing. Analyses included elevation of the site from which seeds were collected for the plants in the experiment, the type of cross, and the identity of the sire treated as fixed effects.

Field Performance. We contacted county weed supervisors across three western states to locate populations that were not under active control to evaluate characteristics of these populations. We visited 33 populations of introduced black henbane in Colorado, Wyoming, and Montana in the summers of 2009, 2010, 2011, and 2012 (Table 1). Additionally, we were able to visit one population in the native range in France in 2010. Black henbane

Table 1. Location and elevation of field observation and seed collection sites, GPS coordinates, and the years in which each site was visited.

\begin{tabular}{|c|c|c|c|c|c|}
\hline State & County & Location & Elevation of site $(\mathrm{m})$ & GPS coordinates & Years visited \\
\hline \multicolumn{6}{|c|}{ Introduced range } \\
\hline \multirow[t]{6}{*}{ Colorado } & Grand & Granby & 2373 & $40.1501,-105.9284$ & $2009,2010,2011$ \\
\hline & & Kremmling & 2402 & $40.1257,-106.3349$ & $2009,2010,2011,2012$ \\
\hline & & Parshall-1 & 2481 & $40.0002,-106.1309$ & 2010,2011 \\
\hline & & Parshall-2 & 2367 & $40.1046,-106.0012$ & $2009,2010,2011,2012$ \\
\hline & & Parshall-3 & 2343 & $40.068,-106.2573$ & $2009,2010,2011,2012$ \\
\hline & & Parshall-4 & 2363 & $40.0349,-106.2382$ & $2009,2010,2011,2012$ \\
\hline \multirow[t]{15}{*}{ Montana } & Beaverhead & Dillon-1 & 1581 & $45.173,-112.7026$ & $2009,2010,2011,2012$ \\
\hline & & Dillon-2 & 1737 & $44.9865,-112.9972$ & $2009,2010,2011,2012$ \\
\hline & & Dillon-3 & 1865 & $44.6976,-112.7098$ & $2009,2010,2011,2012$ \\
\hline & & Dillon-4 & 1986 & $45.168,-112.4303$ & $2009,2010,2011,2012$ \\
\hline & Broadwater & Townsend-1 & 1395 & $46.2248,-111.3733$ & $2010,2011,2012$ \\
\hline & & Townsend-2 & 1160 & $46.3355,-111.5086$ & 2010 \\
\hline & & Townsend-3 & 1429 & $46.252,-111.2929$ & $2010,2011,2012$ \\
\hline & & Townsend-4 & 1222 & $46.3225,-111.5485$ & 2009 \\
\hline & & Townsend-5 & 1436 & $46.3179,-111.6332$ & $2009,2010,2011,2012$ \\
\hline & & Townsend-6 & 1270 & $46.0785,-111.578$ & 2009 \\
\hline & Cascade & Belt & 1228 & $47.2805,-110.8164$ & $2009,2010,2011,2012$ \\
\hline & & Cascade & 1404 & $47.239,-111.8654$ & 2009,2010 \\
\hline & & Great Falls & 1031 & $47.4079,-111.3062$ & 2010 \\
\hline & Park & Livingston-1 & 1369 & $45.6847,-110.5149$ & $2009,2010,2011,2012$ \\
\hline & & Livingston-2 & 1399 & $45.7041,-110.4115$ & $2009,2010,2011,2012$ \\
\hline \multirow[t]{12}{*}{ Wyoming } & Carbon & Arlington & 2356 & $41.6069,-106.2082$ & $2009,2010,2011,2012$ \\
\hline & & Rawlins-1 & 2241 & $41.7491,-106.4638$ & $2009,2010,2011,2012$ \\
\hline & & Rawlins-2 & 2180 & $41.7879,-106.4672$ & 2009 \\
\hline & Park & Cody & 1678 & $44.4832,-109.3459$ & 2009 \\
\hline & Sweetwater & Rock Springs-1 & 2301 & $41.0566,-109.3376$ & $2010,2011,2012$ \\
\hline & & Rock Springs-2 & 2301 & $41.372,-109.139$ & 2010,2012 \\
\hline & & Rock Springs-3 & 2346 & $41.4515,-109.171$ & $2009,2010,2011$ \\
\hline & & Rock Springs-4 & 2244 & $41.3583,-109.2694$ & $2009,2010,2011,2012$ \\
\hline & Teton & Jackson Hole-1 & 1876 & $43.3893,-110.7347$ & $2010,2011,2012$ \\
\hline & & Jackson Hole-2 & 1832 & $43.4249,-110.7757$ & 2010,2011 \\
\hline & & Jackson Hole-3 & 1891 & $43.435,-110.7764$ & 2010,2012 \\
\hline & & Jackson Hole-4 & 1874 & $43.4231,-110.7754$ & 2009,2010 \\
\hline \multicolumn{6}{|l|}{ Native range } \\
\hline France & & Causse-de-la-Selle & 306 & $43.78177,3.60095$ & 2010 \\
\hline
\end{tabular}

86 - Weed Science 65, January-February 2017 
populations in the native range may be ephemeral, as visits were made to 23 sites across southern France known to have black henbane within the previous $3 \mathrm{yr}$, and only one site had a living population. Populations in the introduced range were revisited each year when possible. In each population, we measured plant performance of 6 to 60 individuals. For each individual we recorded whether it was a rosette or bolting plant. For rosettes, we measured size from two perpendicular measurements from leaf tip to leaf tip and calculated rosette area using the formula for an ellipse. For bolting plants, we measured height and counted number of branches containing seed capsules and the total number of developed/ developing seed capsules. We selected plants for measurement from transect(s) that were $25 \mathrm{~m}$ long and $2 \mathrm{~m}$ wide through the most dense area of the population and sampled the plant closest to transect every $1 \mathrm{~m}$. If a population was large enough to hold two transects, then data were recorded from both.

Climate data for each site over the duration of the study were acquired from National Weather Service data (Weather Underground, https://www.wunder ground.com/, 2015). Climate data for each site includes the total precipitation from May through September and for the previous year, mean temperature during May to September, mean temperature during the previous year's winter (November to April), and total growing degree days (GDD) each year and for the previous year. Multiple populations shared the same weather station; therefore populations were sorted by weather station, and Akaike information criterion (AIC) model selection was performed prior to running the models described below.

We evaluated the relationship between plant height and the number of seed capsules produced per plant by the end of July using linear regression. Seed capsule data were log transformed to meet the assumptions of the model. To put the seed capsule data from North American populations into perspective, we compared them with seed capsule counts from two different locations, an introduced population in Britain (from Salisbury 1942) and the native population we sampled in France. The data from these other locations were limited, but a coarse comparison using the $95 \%$ confidence intervals (CIs) around the mean seed capsule production of North American plants, British plants, and French plants was completed.

We used weather data from the nearest weather station of each site to evaluate the effect of climate on seed production. Because many climate variables are correlated, we used AIC model selection to consider seven different location and climate variables and their interactions in nine different statistical models, with seed capsule production and plant height as response variables (Tables 2 to 5). In all of our models, weather station and population nested within weather station were treated as random effects. Both seed capsule data and plant height data were natural log transformed to meet the assumptions of the models.

Seed Ecology. We surveyed the size of soil seed banks in three introduced populations by collecting soil samples from two black henbane populations in southern Wyoming (Arlington and Rock Springs-2; see Table 1) and one population in Colorado (Parshall-3). Soil samples were collected in late October 2011, so the samples likely contained seed deposited from plants that matured in the 2011 growing season in addition to seed from previous seasons. We laid out a $20 \mathrm{~m}$ transect through the densest portion of the black henbane population and collected 20 cylindrical soil cores that were $6.4 \mathrm{~cm}$ in diameter and $3.8 \mathrm{~cm}$ deep at $1 \mathrm{~m}$ intervals along the transect. We used fine sieves to separate materials in

Table 2. Results of AIC model selection for seedpod production.

\begin{tabular}{lcccc}
\hline $\begin{array}{l}\text { Model for seedpods produced } \\
\text { (log transformed) }\end{array}$ & AICc & $\Delta_{i}$ & Akaike weight $\left(w_{i}\right)$ & Likelihood ratio \\
\hline 1 & 1736.7 & 0.0 & 0.832078276 & 1 \\
2 & 1740.7 & 4.0 & 0.112609549 & 0.135335283 \\
3 & 1742.3 & 5.6 & 0.050598732 & 0.060810063 \\
4 & 1747.1 & 10.4 & 0.004590213 & 0.005516564 \\
5 & 1755.1 & 18.4 & $8.40727 \mathrm{E}-05$ & 0.000101039 \\
6 & 1756.9 & 20.2 & $3.41814 \mathrm{E}-05$ & $4.10796 \mathrm{E}-05$ \\
7 & 1760.8 & 24.1 & $4.86313 \mathrm{E}-06$ & $5.84456 \mathrm{E}-06$ \\
8 & 1768.9 & 32.2 & $8.47272 \mathrm{E}-08$ & $1.01826 \mathrm{E}-07$ \\
9 & 1771.2 & 34.5 & $2.68278 \mathrm{E}-08$ & $3.22419 \mathrm{E}-08$ \\
\hline
\end{tabular}


Table 3. Competing models with factors and interactions that were tested for seedpod production using AIC model selection.

\begin{tabular}{|c|c|c|c|c|c|c|c|c|c|}
\hline Factors in the model & Model 1 & Model 2 & Model 3 & Model 4 & Model 5 & Model 6 & Model 7 & Model 8 & Model 9 \\
\hline Elevation of site & & & & $\mathrm{X}$ & $\mathrm{X}$ & $\mathrm{X}$ & $\mathrm{X}$ & $\mathrm{X}$ & \\
\hline $\begin{array}{l}\text { Previous year's total growing degree } \\
\text { days May } 1 \text { to September } 30\end{array}$ & & $\mathrm{X}$ & $\mathrm{X}$ & & $\mathrm{X}$ & $\mathrm{X}$ & & $\mathrm{X}$ & \\
\hline $\begin{array}{l}\text { Previous year's total precipitation } \\
\text { May } 1 \text { to September } 30\end{array}$ & & & $\mathrm{X}$ & & $\mathrm{X}$ & $\mathrm{X}$ & & $\mathrm{X}$ & \\
\hline $\begin{array}{l}\text { Total growing degree days May } 1 \\
\text { to September } 30\end{array}$ & $\mathrm{X}$ & $\mathrm{X}$ & $\mathrm{X}$ & & $\mathrm{X}$ & $\mathrm{X}$ & $\mathrm{X}$ & $\mathrm{X}$ & \\
\hline $\begin{array}{l}\text { Total precipitation May } 1 \text { to September } 30 \\
\text { laggdd*lagprecip } \\
\text { gdd*precip }\end{array}$ & $\mathrm{X}$ & $\mathrm{X}$ & $\mathrm{X}$ & & & $\mathrm{X}$ & $\mathrm{X}$ & $\mathrm{X}$ & $\begin{array}{l}X \\
X\end{array}$ \\
\hline
\end{tabular}

the samples based on size. Large rocks and fine dirt were discarded, and the remaining sample was mixed in a beaker with water. We then poured the floating organic matter over coffee filters and allowed the processed organic matter from the soil samples to dry. Black henbane seeds were identified using a dissection microscope, removed from the soil samples, and counted.

As a corollary to the seed bank question, we performed a germination experiment in a growth chamber at Colorado State University with seeds collected from plants in the field in an effort to determine whether seeds remain viable multiple years. We used seed collected from four Colorado populations, three Wyoming populations, and two Montana populations in this experiment. Seeds were collected in the fall of 2008, 2009, 2010, and 2011 and stored at $2 \mathrm{C}$ until they were used in this experiment in November 2012. Fifty seeds from mixed maternal sources but collected from the same population were placed on moist filter paper in plastic petri dishes. Filter paper was watered twice daily to maintain moist conditions. All seeds were kept in a germination chamber set to a $14 / 10 \mathrm{~h}$ day/ night photoperiod and $20 \mathrm{C}$ temperature. As seeds germinated each day they were counted and removed from the dish. We ended the experiment after $22 \mathrm{~d}$, at which point germination rate across all dishes had greatly decreased and $3 \mathrm{~d}$ had passed with no germination at all.

We used a mixed linear model (PROC MIXED) to evaluate the difference in germination rates of seeds collected from plants in different years. Analysis included the collection year and the total GDD at the site during May 1 to September 30 of the collection year as fixed effects with state treated as a random effect. Germination rates were $\log$ transformed to meet the assumptions of the model.

Population Dynamics. To determine the average size and variation of the size of introduced populations and trends in population growth and/or decline over multiple growing seasons, we visited naturalized populations of black henbane. For this effort, it was important that sites we surveyed were not treated with herbicides or other weed management practices. Although control efforts for this species are active and ongoing, we were able to sample 15 sites in Montana, Wyoming, and Colorado in July of 2009, 2010, 2011, and 2012. At each site, we counted the number of rosettes, the number of adult plants, and the total number of plants at each site.

We used repeated-measures analysis with mixed linear models (PROC MIXED) to determine the

Table 4. Results of AIC model selection for plant height.

\begin{tabular}{lcccc}
\hline $\begin{array}{l}\text { Model for plant height } \\
\text { (log transformed) }\end{array}$ & AICc & $\Delta_{i}$ & Akaike weight $\left(w_{i}\right)$ & Likelihood ratio \\
\hline 1 & 978.4 & 0.0 & 0.932298177 & 1 \\
2 & 984.7 & 6.3 & 0.03995096 & 0.042852127 \\
3 & 985.5 & 7.1 & 0.026779929 & 0.02872464 \\
4 & 992.9 & 14.5 & 0.000662094 & 0.000710174 \\
5 & 995.0 & 16.6 & 0.000231692 & 0.000248517 \\
6 & 997.2 & 18.8 & $7.71235 \mathrm{E}-05$ & $8.27241 \mathrm{E}-05$ \\
7 & 1013.4 & 35.0 & $2.341 \mathrm{E}-08$ & $2.511 \mathrm{E}-08$ \\
8 & 1020.1 & 41.7 & $8.21325 \mathrm{E}-10$ & $8.80968 \mathrm{E}-10$ \\
9 & 1039.0 & 60.6 & $6.46297 \mathrm{E}-14$ & $6.9323 \mathrm{E}-14$ \\
\hline
\end{tabular}


Table 5. Competing models with factors and interactions that were tested for plant height using AIC model selection.

\begin{tabular}{|c|c|c|c|c|c|c|c|c|c|}
\hline Factors in the model & Model 1 & Model 2 & Model 3 & Model 4 & Model 5 & Model 6 & Model 7 & Model 8 & Model 9 \\
\hline Elevation of site & $\mathrm{X}$ & $\mathrm{X}$ & $\mathrm{X}$ & & $\mathrm{X}$ & & $\mathrm{X}$ & & \\
\hline $\begin{array}{l}\text { Previous year's total growing degree } \\
\text { days May } 1 \text { to September } 30\end{array}$ & $\mathrm{X}$ & $\mathrm{X}$ & $\mathrm{X}$ & & & $\mathrm{X}$ & & & \\
\hline $\begin{array}{l}\text { Previous year's total precipitation May } 1 \\
\text { to September } 30\end{array}$ & $\mathrm{X}$ & $\mathrm{X}$ & $\mathrm{X}$ & & & $\mathrm{X}$ & & & \\
\hline $\begin{array}{l}\text { Total growing degree days May } 1 \\
\text { to September } 30\end{array}$ & $\mathrm{X}$ & $\mathrm{X}$ & $\mathrm{X}$ & $\mathrm{X}$ & $\mathrm{X}$ & $\mathrm{X}$ & & & \\
\hline $\begin{array}{l}\text { Total precipitation May } 1 \text { to September } 30 \\
\text { laggdd*lagprecip } \\
\text { gdd*precip }\end{array}$ & & $\mathrm{X}$ & $\mathrm{X}$ & $\mathrm{X}$ & $\mathrm{X}$ & $\mathrm{X}$ & & $\mathrm{X}$ & $\begin{array}{l}X \\
X\end{array}$ \\
\hline
\end{tabular}

factors that influence population size through time. Our models included the previous year's population size as a fixed effect. Population size data were log $(\mathrm{N}+1)$ transformed to meet the assumptions of the model. We included a number of climatic variables and population attributes in the analyses in an effort to predict population size from one year to the next. These variables included site elevation, total precipitation at the site May through September and the total precipitation during the previous year, mean temperature at the site May through September, number of GDD May through September, the total number of plants in the population the previous year, the yearly number of rosettes present in the population and in the previous year, and the yearly number of flowering plants present in the population and in the previous year.

Demography. To determine the timing and frequency of plant mortality in introduced populations, we marked and tracked plants throughout their life cycles at two field sites. We visited sites located in Colorado (Parshall-3) and Wyoming (Arlington) in late May, mid-July, and late September of 2011, and late June 2012. Plants at these sites were not sprayed with herbicides or managed by landowners or county weed managers over the course of data collection. Two 1 by $9.7 \mathrm{~m}$ transects at each site were marked with stakes, and the boundaries of sixty 30.5 by $48 \mathrm{~cm}$ quadrats within those transects were marked with nails. Uniquely numbered metal tags were nailed into the ground at the base of rosettes to mark all black henbane rosettes within each transect. Due to the locations of the populations, we were unable to observe and mark black henbane seedlings. Therefore, seedling emergence and mortality were not recorded. New rosettes were tagged as they were found in late May and mid-July 2011 at both sites. To estimate rosette size, we counted the total number of rosette leaves, measured the area of each rosette, and recorded the length and width of the largest rosette leaf at our Colorado site in July 2011. Additionally, we assigned an herbivory rating to each rosette using the scale presented in Lewis et al. (2006). Finally, we measured vegetation composition and competition using two Daubenmire frames placed on opposite sides of the rosette and estimated percent cover of forbs, grasses, rocks, litter, bare ground, and other black henbane plants for each rosette at both sites in late September 2011. Our final data collection at both sites was in June of 2012. At this point all plants were either bolting or dead, and we measured the height of all flowering plants, the number of branches, the total number of seed capsules, and an herbivory score of each adult plant. Our count of seed capsules was not the total seed produced by each plant (because we visited in June rather than the fall), but our counts give a good comparison of plant size and maturity between the two henbane populations.

We used mixed linear models (PROC MIXED) to evaluate the effect of climate and first-year plant characteristics on mature plant size (e.g., plant height and number of branches) and reproduction. We treated September 2011 rosette size and the interaction between mean temperature in 2011 and total precipitation in 2011 as fixed effects and population as a random effect. June 2012 plant height data were square-root transformed to meet the assumptions of the model. Next, we used a generalized linear mixed model with binary distribution to assess the effect of first-year plant characteristics, insect herbivory, and bare ground (i.e., competition) on plant overwintering survival. Analyses included population, rosette size in September 2011, the level of aboveground herbivory as measured in September, and the amount of bare ground around each rosette, which were all treated as fixed effects. 


\section{Results and Discussion}

Reproduction. The greenhouse pollination experiment showed that self-pollination can produce viable seeds. Hand pollination improved seed production in selfed flowers, with hand-pollinated flowers producing, on average, a little more than twice as many seeds than flowers that were bagged, but not pollinated by hand $\left(\mathrm{F}_{1,29}=10.11, \mathrm{P}=0.0035\right)$. Thus, introduced black henbane has the ability to self, and outcrossing is not obligate.

The family Solanaceae is largely self-incompatible, with the self-incompatibility mechanism (S-locus) being basal to the group, and approximately 90 million years old (Steinbachs and Holsinger 2002). Some solanaceous species retain the ancestral self-incompatibility mechanism (Igic et al. 2004; Miller et al. 2008; Richman and Kohn 2000), while many have transitioned to self-compatible (Igic et al. 2004, 2006). This shift is one of the most common evolutionary changes in angiosperms (Stebbins 1974). Self-incompatibility is often lost within a taxon, and the transition is rarely, if ever, reversed (Igic et al. 2008). Results from our pollination experiment are the first confirmation of selfcompatibility in introduced black henbane and the only confirmation for the species in the published (English language) literature. Whether native populations of this species are able to self is unknown. It is conceivable that introduced populations of henbane may have evolved the ability to self over time, either prior to or following introduction, and that selfcompatibility may facilitate the spread of this species (Stebbins 1957; and see Baker 1967).

Surprisingly, black henbane does not benefit from outcrossing with plants from other populations, with comparable amounts of seed produced when plants were crossed with siblings, other plants within the same populations, or plants from different populations $\left(\mathrm{F}_{1,4}=0.12, \mathrm{P}=0.7507\right)$. There was also no significant difference in mass of individual seeds $\left(\mathrm{F}_{1,47}=0.37, \mathrm{P}=0.5438\right)$ between crosses. Therefore the similar results across cross types reflect not only the overall seed mass produced but also the number of seeds produced.

In a predominantly self-fertilizing population, selection against deleterious alleles will be strong, and after such alleles are purged from a population, the potential advantages of outcrossing will be reduced. True to the models presented by Stebbins (1957) and Lande and Schemske (1985), black henbane is a selfing, introduced species that does not show an advantage from outcrossing in this study.
Alternatively, the lack of an outcrossing advantage shown in our pollination experiment could be because introduced populations of henbane may already have high genetic diversity within populations. It is also possible that we do not see an advantage from outcrossing in our experiments because in this system, an advantage may not be expressed until the plant is older, sometime after seed production and germination.

The crosses conducted in the greenhouse produced substantial numbers of seeds, comparable to the number of seeds per capsule produced by plants in the field. A random collection of 48 mature, unopened seed capsules from Kremmling, CO, and Arlington, WY, yielded an average of $219.95 \pm 10.07 \mathrm{mg}$ of seeds per capsule. Our selfed crosses in the greenhouse produced an average of $187.87 \pm 14.90 \mathrm{mg}$ of seeds per capsule $(85.4 \%$ of the average yield of field plants), while our outcrossed plants in the greenhouse produced an average of $207.48 \pm 0.09 \mathrm{mg}$ of seeds per capsule ( $94.3 \%$ of the average yield of field plants).

It is important to note that the mass of seeds produced in our two greenhouse pollination experiments should not be compared. Anthers were left intact in our self-pollination experiment, whereas anthers were removed in all of the treatments in our outcrossing experiment. In a separate experiment we found a significant effect of anther presence, whereby removing anthers actually increased seed set (unpublished data).

The mass of the seeds produced was linked to germination rates such that crosses that produced lower total seed mass had lower germination rates $\left(\mathrm{F}_{1,15}=19.68, \mathrm{P}=0.0005\right.$; Figure 1$)$. This trend is not consistent but is statistically significant. In general, though, germination rates were high:

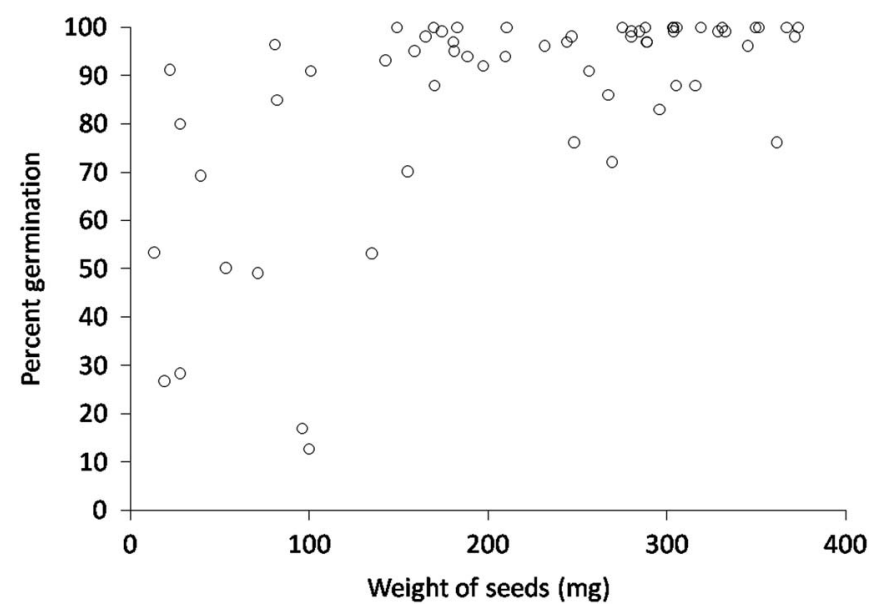

Figure 1. Percent germination of seeds produced in the pollination experiment. 
between 76.6 and $97.6 \%$ germination (Figure 1). The elevation at which the maternal plant was collected $\left(\mathrm{F}_{1,15}=0.07, \mathrm{P}=0.7954\right)$, the cross performed $\left(\mathrm{F}_{1,15}=1.54, \mathrm{P}=0.2338\right)$, and the sire $\left(\mathrm{F}_{29,15}=1.23, \mathrm{P}=0.3436\right)$ did not affect germination rates.

Field Performance. On average across all populations, an individual plant produces $115 \pm 18.2$ (mean $\pm 95 \% \mathrm{CI}$ ) seed capsules (estimated to be $25,300 \pm 4,004$ seeds) by the end of July. This contrasts with data from 1936 and 1939 in introduced British populations (Salisbury 1942). There, plants produced an average of only $19 \pm 3.5$ seed capsules. In southern France (the native range) in 2010 , one population of 17 plants had an average of $52 \pm 19.6$ seed capsules per plant. None of these CIs overlap, establishing that our North American plants in the introduced range produce significantly more seed capsules than not only the population in France (native range) but also plants in Britain $80 \mathrm{yr}$ ago. Though the native range data were scant, they were consistent with a pattern seen in many other invaders: introduced individuals and populations were larger (Abela-Hofbauerová and Munzbergová 2011; Blumenthal and Hufbauer 2007; Brown and Eckert 2005; Dlugosch and Parker 2008; Flory et al. 2011; Fukano and Yahara 2012; Harris et al. 2012; Hodgins and Rieseberg 2011; Huang et al. 2012; Keller and Taylor 2010; Lavergne and Molofsky 2007; Rogers and Siemann 2005; Wolfe et al. 2004).

Our field data showed that plant height was a good predictor of the number of seed capsules $\left(\mathrm{R}^{2}=0.61, \quad \mathrm{~F}_{1,523}=787.19, \quad \mathrm{P}<0.0001\right.$;

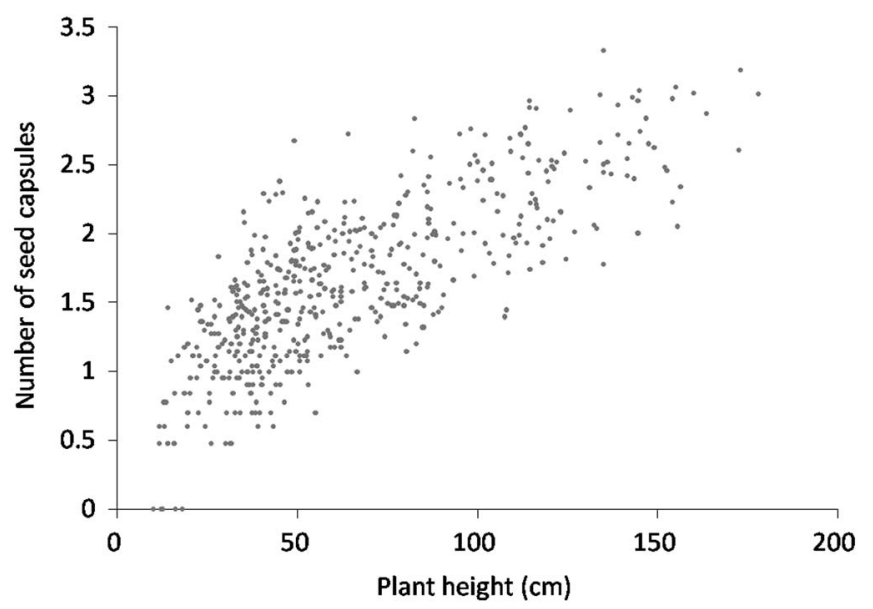

Figure 2. Relationship between plant height observed in naturalized populations in the field and the number of seed capsules present on each plant in July. Data have been log transformed for this figure.
Figure 2). Model selection revealed precipitation and GDD to be most influential on seed capsule production, and site elevation, precipitation, and GDD to be most influential on plant height (corrected Akaike information criterion [AICc] are given in Table 2). The best model for seed capsule production included total number of GDD May 1 to September 30 and total precipitation May 1 to September 30 as fixed effects (Table 3). The best model for plant height included total number of GDD May 1 to September 30, the previous year's total precipitation May 1 to September 30, the previous year's total GDD May 1 to September 30, and site elevation as fixed effects (Tables 4 and 5).

More precipitation during the second summer, when seeds were formed, increased seed output $\left(F_{1,496}=4.56, P=0.0333\right)$. Plants also had greater yield $\left(\mathrm{F}_{1,496}=16.11, \mathrm{P}<0.0001\right)$ but were smaller in stature $\left(\mathrm{F}_{1,748}=42.19, \mathrm{P}<0.0001\right)$ when they experienced a greater number of GDD during the second summer of growth.

Of the populations we studied, plants at higher elevations (and lower latitudes) were shorter $\left(\mathrm{F}_{1,31}=37.47, \quad \mathrm{P}<0.0001\right)$. More GDD $\left(\mathrm{F}_{1,748}=5.05, \mathrm{P}=0.0249\right)$ and more precipitation $\left(\mathrm{F}_{1,748}=16.82, \mathrm{P}<0.0001\right)$ during the rosette stage also yielded shorter second-year, mature plants.

Our studies showed a significant effect of GDD leading to higher seed output of black henbane plants. Higher moisture levels (between 10 and $31 \mathrm{~cm}$ during the growing season) and temperatures (average minimum temperature of $4 \mathrm{C}$ and average maximum temperature of $23 \mathrm{C}$ ) lead to higher survival and fitness of black henbane. As the climate changes and temperatures increase, we may see black henbane populations change to be denser and less ephemeral. Higher seed production in introduced plant species has been documented in other systems as a result of climate change (Redman et al. 2011; Smith et al. 2000; Wookey et al. 1993) and thus should be seriously considered in future research of black henbane.

Seed Ecology. We collected as many as 469 seeds from a single soil sample $\left(122 \mathrm{~cm}^{3}\right)$. At that density there could be 146,093 seeds $\mathrm{m}^{-2}$. On average, across all three sites, we estimate 15,596 $\$ 4406$ seeds $\mathrm{m}^{-2}$. The greatest average density of seeds at one site, $33,424 \pm 9140$ seeds $\mathrm{m}^{-2}$, was found at Arlington, WY (see Table 1 for location). This is likely due to the high plant density (average of 9 plants $\mathrm{m}^{-2}$ ) at that site.

Germination success of field-collected seed did not differ by collection year $\left(\mathrm{F}_{1,69}=1.81\right.$, 
$\mathrm{P}=0.1834)$. Germination rates were $12.6 \pm 5.3 \%$, $29.9 \pm 7.1 \%, 24.1 \pm 4.3$, and $16.0 \pm 9.1 \%$ for seeds that were 1, 2, 3, or 4 yr old, respectively.

Henbane seeds typically fall to the ground directly below the plant where they are produced. This creates soil seed banks that are rich with henbane seed in the top $3.8 \mathrm{~cm}$ of soil. Intuitively, the size of the seed bank increases with plant density. Seeds remain viable over multiple years with no obvious difference in germination rates among seeds that have matured in the last year as opposed to seeds that matured $4 \mathrm{yr}$ earlier. Other than chilling (storage of seeds in a refrigerator) we did not use any form of chemical germination promoter or scarification in our seed germination experiment.

We did, however, notice a difference in germination rates when comparing our pollination seed germination results to our field-collected seed germination results. Seeds produced from our pollination experiment had a higher overall germination rate $(85 \%)$ while field-collected seed had a much lower germination rate (20\%; unpublished data). Seeds germinated in both experiments were stored for similar amounts of time at the same temperature, and both germination experiments were carried out following the same protocol (i.e., similar light regime, temperature, and moisture). Seeds were also collected from plants in the greenhouse and from plants in the field at the same point of seed capsule maturity. We hypothesize that hand pollination produces seeds with higher germination rates when compared with naturally pollinated seeds in the field. Lower germination rates in fieldpollinated seeds may be attributed to a pollentransmitted fungal pathogen or virus vectored by a pollinator, as has been observed with Tobacco ringspot virus, which is known to infect solanaceous plants (Yang and Hamilton 1974). However, other studies that include the germination of henbane seeds report varying levels of success, between 0 and $80 \%$ germination, so it is possible that germination of henbane seeds is inherently variable (Cirak et al. 2004; Sharma et al. 2006). We should note that we tested germination success of black henbane seeds, not viability of the seeds.

The germination rates observed in our trial with field-collected seeds are reasonably comparable to natural germination rates that would occur in the field (Radosevich et al. 1997). We note from field observations that germination begins as early as May and may occur as late as October (CEF, personal observations and unpublished data). While we know that populations are not inhibited due to a lack of seeds, populations are not consistently large in size.
Thus the size of soil seed banks and seed germination rates are not likely to limit population size after initial establishment.

Population Dynamics. Surveys of population characteristics and size reveal that black henbane populations in the survey area were found exclusively in highly disturbed sites, with the disturbances almost exclusively human caused (e.g., pipeline rights-of-way, construction areas, drainage ditches; $\mathrm{CEF}$, personal observations). Interestingly, the size of invasive populations fluctuates dramatically from year to year (Figure 3). There was no consistent pattern of population growth or decline, rather populations increased in size by up to 40 -fold and decreased in size by up to 100 -fold over the course of three growing seasons (Figure 3).

Of all the plant count, location, and climate factors that were included in our model, the only climatic factor that had an influence on total population size was total precipitation: a population that experienced higher levels (minimum of $10 \mathrm{~cm}$ of total precipitation but as much as $31 \mathrm{~cm}$ during the growing season) of precipitation one year was likely to have a larger total population size the following year $\left(F_{1,29}=6.65\right.$, $\mathrm{P}=0.0152)$. Surprisingly, even the total population size one year did not predict the next year's total population size $\left(F_{1,29}=0.60, P=0.4453\right)$, though the number of rosettes present in a population at the end of July was positively associated with the number of flowering plants in that population the following year $\left(\mathrm{F}_{1,29}=8.01, \mathrm{P}=0.0084\right)$.

Demography. Plants that were tagged and monitored from May 2011 to June 2012 at two

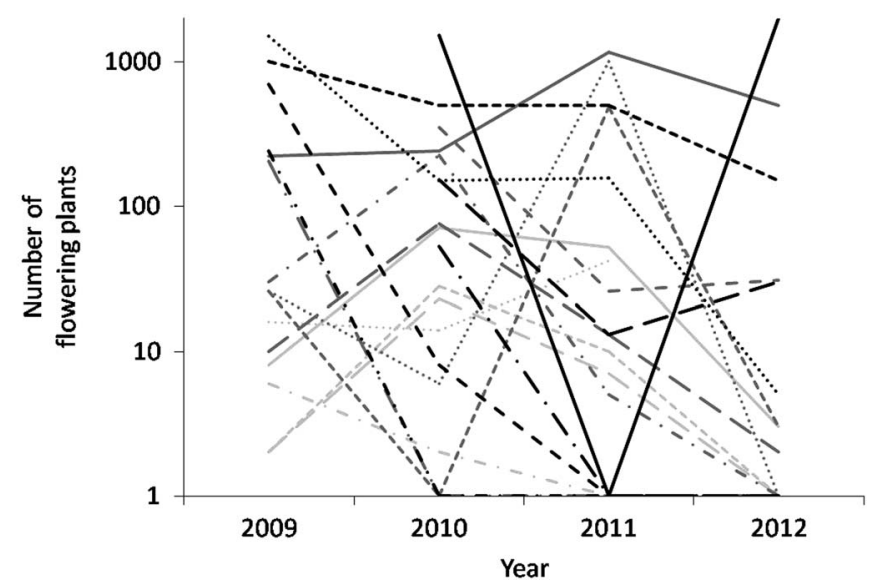

Figure 3. Data (transformed on a log scale) indicate the larger pattern of population dynamics within and among study sites in Colorado, Montana, and Wyoming. There are dramatic fluctuations in population sizes over three growing seasons. 


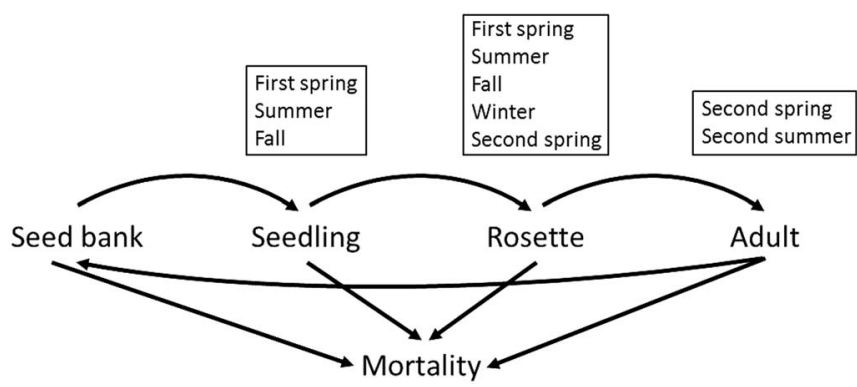

Figure 4. Schematic diagram of the life cycle of black henbane. Seasonal timing of each stage of plant growth is represented in the boxes above each growth stage.

locations revealed timing of both germination and mortality (Figure 4). While both germination and mortality span the entire length of the growing season, typically May to September, there were two main periods when rosette death occurred: July to September, when the plants were first-year rosettes, and over winter (Figure 5). The Wyoming site experienced the biggest loss (57\%) in number of rosettes between July and September, while the Colorado site had the biggest loss of rosettes (63\%) over the winter (Figure 5). Overall, 18.4\% of all tagged Colorado plants survived to reproduce, while $30.8 \%$ of all tagged Wyoming plants survived to reproduce. Interestingly, smaller rosettes in September 2011 not only survived the winter but became the taller plants in June $2012 \quad\left(\mathrm{~F}_{1,44}=9.95\right.$, $\mathrm{P}=0.0029)$. We hypothesize that rosettes that germinate later in the summer and are therefore smaller in the fall are subjected to less intense abiotic and

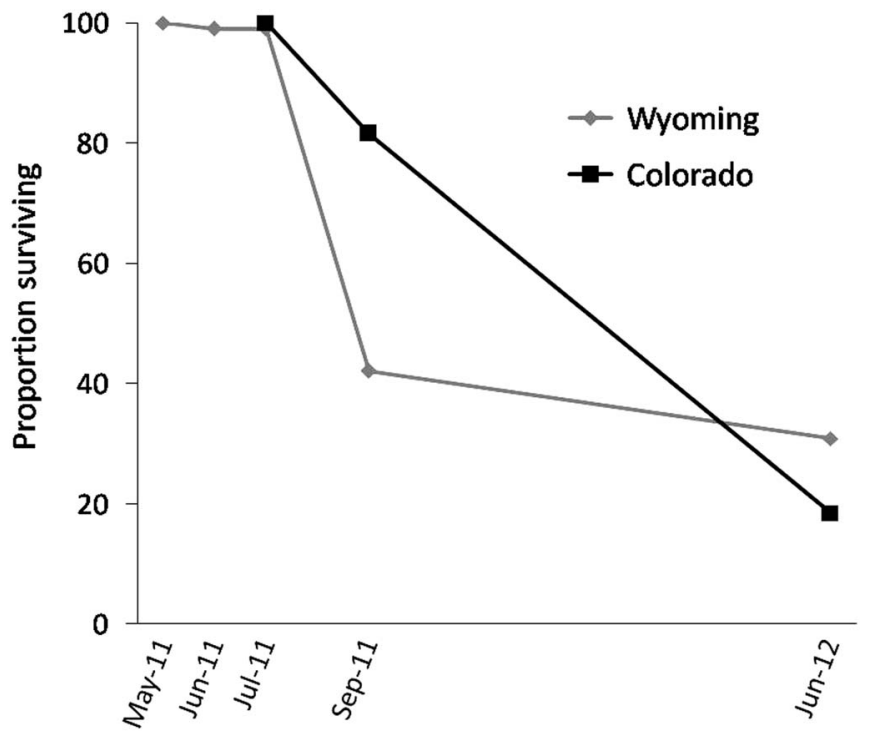

Figure 5. The proportion of henbane plants in our demography study that survived over time. Data are from two locations in Colorado and Wyoming. The $y$-axis has a logarithmic scale. biotic selective pressures (e.g., drought stress, herbivory) and for a shorter time before the rosette goes dormant for the winter months. It is possible that the smaller rosettes may also allocate a greater proportion of resources to belowground biomass versus aboveground rosette size. This allocation of resources in the summer and fall of the first year may contribute to a more robust and taller plant the following spring.

In addition to monitoring plant survival, we also evaluated the effects of climate variables on plant performance. Plants that experienced the 2011 growing season (May 1 to September 30, 2011) with a higher mean temperature and more precipitation (the Wyoming plants) were taller (precip11*temp11, $\mathrm{F}_{1}, 44=154.41, \mathrm{P}<0.0001$ ), had more branches $\left(\mathrm{F}_{1}, 44=45.59, \mathrm{P}<0.0001\right)$, and had more seed capsules $\left(\mathrm{F}_{1,44}=27.34\right.$, $\mathrm{P}<0.0001)$ when they were measured in June 2012.

Overwintering survival of rosettes differed significantly between populations $\left(\mathrm{F}_{1,102}=6.86\right.$, $\mathrm{P}=0.0101)$, but rosette area in September 2011 $\left(\mathrm{F}_{1,102}=0.30, \mathrm{P}=0.5872\right)$, level of aboveground herbivore damage $\left(\mathrm{F}_{1,102}=1.69, \mathrm{P}=0.1966\right)$, and the amount of bare ground $\left(\mathrm{F}_{1,102}=0.17\right.$, $\mathrm{P}=0.6847$ ) did not predict overwintering survival well. Within the individual populations, none of the variables we tested predicted overwintering survival well, though there was a trend that rosettes that were surrounded by more bare ground in 2011 had a higher probability of survival $\left(\mathrm{F}_{1,43}=0.04\right.$, $\mathrm{P}=0.8519$; Figure 6).

In our demography study both populations exhibited great fluctuation in total size over time and considerable plant mortality in the middle of the growing season. Although plant mortality may vary from year to year and our study only covered one growing season, the amount of total plant mortality over the growing season that we recorded at our Wyoming site (69.2\%) and our Colorado site $(81.6 \%)$ was similar to that found in other overwintering biennial plant species (common mullein (Verbascum thapsus L.) Gross 1981 [79, 30, 57, and $38 \%$ mortality]; hawkweed oxtongue (Picris hieracioides L.) Klemow and Raynal 1985 [55-70 and 80\%]; Lysimachia rubida Koidz. Suzuki et al. 2003 [94 and 98\%]).

Populations of introduced henbane vary in number of individuals from one location to another and from year to year (Figure 3). If black henbane were aggressively invasive in this region, then we would expect populations to increase in size over time, but they did not. We should note that our selection of a limited number of unmanaged sites 


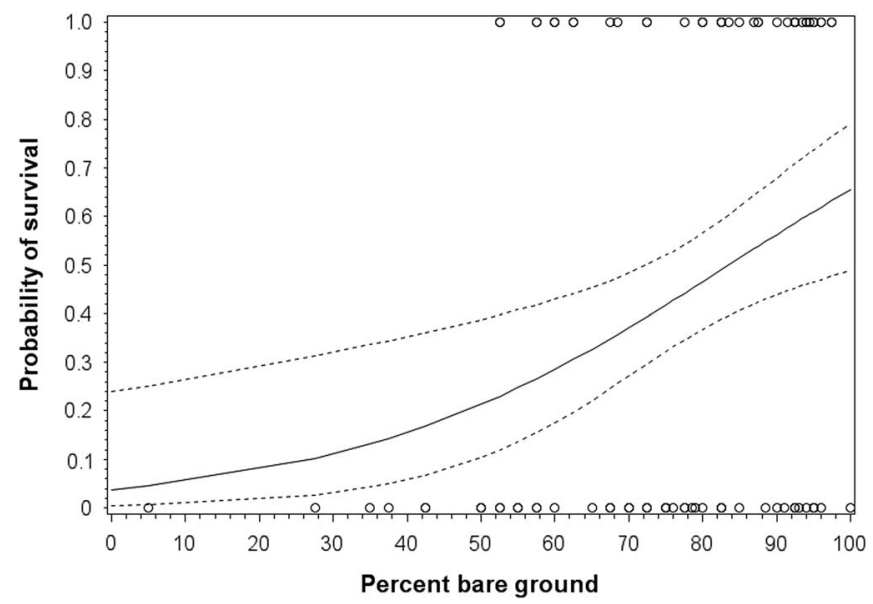

Figure 6. Percent bare ground surrounding each plant (open circles) versus the probability of the plant's survival. The solid line is the direct logistic regression, and the dashed lines are 95\% CIs.

was not a random sample, and so the populations used in this study might be smaller populations than those populations managed at other locations. The dynamic fluctuations in population size of the locations we studied could be due to climatic factors. In both our field survey of population size changes over time and our demography study, higher levels of total precipitation at a site led to high-yielding mature plants and larger overall population sizes. Population sizes fluctuate dramatically between years and cannot be predicted confidently from one year to the next because future precipitation levels, the size of the soil seed bank, and availability of open spaces for germination are typically unknown.

Water availability and competition with other plants are probably the most limiting factors to henbane population size and growth. Selleck (1964) found that seeding an already infested area of henbane with crested wheatgrass or bromegrass resulted in complete control of the henbane. He also found, however, that black henbane infestations maintained their vigor in areas with greater water availability (Selleck 1964). More recently LaFantasie and Enloe (2011) presented henbane as a poor competitor in their experiment with three native grasses that are typically used in restoration projects. Total biomass of henbane was found to be as much as $99 \%$ lower when the plants were grown in the same pot as mature grasses. Competition with henbane had little effect on the species used as competitors (LaFantasie and Enloe 2011).

Our data emphasize the importance of precipitation for henbane populations to be large and composed of high-yielding plants. If water availability and competition are indeed limiting factors for henbane population success, then populations will likely be more successful and therefore more problematic in areas that experience adequate rainfall and have less competition from other vegetation. Black henbane is likely not a bigger problem in the eastern United States due to the fact that it is a poor competitor (LaFantasie and Enloe 2011).

Introduced henbane is able to self, and plants produce copious seed. Seed banks are large, and seeds remain viable for at least $4 \mathrm{yr}$ with no apparent decline in viability. Growing seasons with more GDD and ample precipitation (between 10 and $31 \mathrm{~cm}$ of total precipitation during the growing season) encourage large population sizes, although population sizes fluctuate dramatically over time. When there is population decline, it may be due to the high number of rosettes that do not survive the winter. It is possible that introduced populations of henbane will naturally fluctuate and disappear (without the need for common weed management practices and herbicide application) when they are outcompeted by native or other introduced plant species. We now know that populations in the western United States are ephemeral, but the seed banks and potential for large population outbreaks are present. Future studies on the ecology of black henbane, specifically an estimate of the longevity of its seed bank and experiments that encompass how black henbane will respond to climate change, will equip land managers with more information for their management decision-making process.

Black henbane is prolific and has been shown to cause serious threats to livestock and humans. Given that this weed is toxic, it is crucial to identify infestations and manage populations. To do this, plants should be controlled prior to seed set. Where populations persist, it is best to control henbane infestations with tillage and planting of competitive native grasses and plants. We have shown that population sizes can decrease dramatically from just one growing season to the next, and we know that competition plays a role in performance (LaFantasie and Enloe 2011). These factors suggest that restoration efforts, rather than herbicide application, may be valuable in the long-term management of black henbane.

\section{Acknowledgments}

The authors thank Colorado, Montana, and Wyoming state weed supervisors, C. Alba, J. Fettig, E. Freeland, G. Hardy, P. Hardy, and M. Nelson for their help with 
field data and seed collection. Thanks to J. Matsuura for assistance in the greenhouse. Appreciation is extended to A. Norton and J. zumBrunnen for advice on data analyses. Thanks also to A. Norton, J. McKay, J. Savidge, and two anonymous reviewers for comments on the manuscript. The Colorado Agricultural Experiment Station and the USDA provided funding for this research.

\section{Literature Cited}

Abela-Hofbauerová I, Münzbergová Z (2011) Increased performance of Cirsium arvense from the invasive range. Flora 12:1012-1019

Baker HG (1967) Support for Baker's law-as a rule. Evolution 21:853-856

Beasley V (1999) Toxicants that affect the autonomic nervous system (and, in some cases, voluntary nerves as well). Pages 8-9 in Beasley V, ed. Veterinary Toxicology. New York: International Veterinary Information Service

Biswas K (1956). Common Medicinal Plants of Darjeeling and Sikkim Himalaya. West Bengal, Calcutta: Bengal Government Press. P 71

Blumenthal DM, Hufbauer RA (2007) Increased plant size in exotic populations: a common-garden test with 14 invasive species. Ecology 11:2758-2765

Brown JS, Eckert CG (2005) Evolutionary increase in sexual and clonal reproductive capacity during biological invasion in an aquatic plant Butomus umbellatus (Butomaceae). Am J Bot 3:495-502

Capinera JL (2014). Giant African land snail in Florida. Gainesville, FL: University of Florida IFAS extension document ENY-512 (IN904). http://edis.ifas.ufl.edu/in904. Accessed: March 4, 2016

Cirak C, Kevseroglu K, Saglam B (2004) Physical and physiological dormancy in black henbane (Hyoscyamus niger L.) seeds. J Plant Biol 4:391-395

Cooper MR, Johnson AW (1984). Poisonous plants in Britain and their effects on animals and man. London: Her Majesty's Stationery Office. $305 \mathrm{p}$

Correns C (1904) Eintypischerspaltender Bastard zwischeneinereinjährigen und einerzweijährigen Sippe des Hyoscyamus niger. Berichte der Deutschen Botanischen Gesellschaft 22: 517-524

Couch JF (1937) The chemistry of stock-poisoning plants. J Chem Educ 1:16-30

Dlugosch K, Parker I (2008) Founding events in species invasions: genetic variation, adaptive evolution, and the role of multiple introductions. Mol Ecol 1:431-449

Doneray H, Orbak Z, Karakelleoglu C (2007) Clinical outcomes in children with hyoscyamus niger intoxication not receiving physostigmine therapy. Eur J Emerg Med 6:348-350

Fettig C, Hufbauer R (2014) Introduced North American black henbane (Hyoscyamus niger) populations are biennial. Invasive Plant Sci Manag 4:624-630

Flory SL, Long F, Clay K (2011) Greater performance of introduced vs. native range populations of Microstegium vimineum across different light environments. Basic Appl Ecol 4:350-359

Fukano Y, Yahara T (2012) Changes in defense of an alien plant Ambrosia artemisiifolia before and after the invasion of a native specialist enemy Ophraella communa. PLoS ONE 7: e49114
Gross KL (1981) Predictions of fate from rosette size in four "biennial" plant species: Verbascum thapsus, Oenothera biennis, Daucus carota, and Tragopogon dubius. Oecologia 2:209-213

Häkkinen ST, Moyano E, Cusidó RM, Palazón J, Piñol MT, Oksman-Caldentey KM (2005) Enhanced secretion of tropane alkaloids in Nicotiana tabacum hairy roots expressing heterologous hyoscyamine-6 $\beta$-hydroxylase. J Exp Bot 420:2611-2618

Harris CJ, Dormontt EE, Le Roux JJ, Lowe A, Leishman MR (2012) No consistent association between changes in genetic diversity and adaptive responses of Australian acacias in novel ranges. Evol Ecol 6:1345-1360

Hodgins KA, Rieseberg L (2011) Genetic differentiation in lifehistory traits of introduced and native common ragweed (Ambrosia artemisiifolia) populations. J Evol Biol 12:2731-2749

Huang W, Carrillo J, Ding J, Siemann E (2012) Interactive effects of herbivory and competition intensity determine invasive plant performance. Oecologia 2:373-382

Husain A, Singh P, Singh A (1979) Introduction of a high alkaloid strain of Hyoscyamus muticus in India. Indian J Pharm Sci 41:46-48

Igic B, Bohs L, Kohn JR (2004) Historical inferences from the self-incompatibility locus. New Phytol 1:97-105

Igic B, Bohs L, Kohn JR (2006) Ancient polymorphism reveals unidirectional breeding system shifts. Proc Natl Acad Sci USA 5:1359-1363

Igic B, Lande R, Kohn JR (2008) Loss of self-incompatibility and its evolutionary consequences. Int J Plant Sci 1:93-104

Keller S, Taylor D (2010) Genomic admixture increases fitness during a biological invasion. J Evol Biol 8:1720-1731

Klemow KM, Raynal DJ (1985) Demography of two facultative biennial plant species in an unproductive habitat. J Ecol 1:147-167

Knight AP, Walter RG (2003) Plants affecting the digestive system. Page 367 in Knight AP \& Walter RG eds, A Guide to Plant Poisoning of Animals in North America. Jackson, WY: Teton New-Media

Kurkcuoglu M (1970) Henbane (Hyoscyamus niger) poisonings in the vicinity of Erzurum. Turk J Pediatr 1:48-56

LaFantasie JJ, Enloe SF (2011) Competitive ability of black henbane (Hyoscyamus niger) when grown with three native grasses. Invasive Plant Sci Manag 4:159-165

Lande R, Schemske DW (1985) The evolution of self-fertilization and inbreeding depression in plants. I. Genetic models. Evolution 1:24-40

Lavergne S, Molofsky J (2007) Increased genetic variation and evolutionary potential drive the success of an invasive grass. Proc Natl Acad Sci 10:3883-3888

Lewis KC, Bazzaz FA, Liao Q, Orians CM (2006) Geographic patterns of herbivory and resource allocation to defense, growth, and reproduction in an invasive biennial, Alliaria petiolata. Oecologia 148:384-395

Lindequist U (1993). Pages 460-474 in Lindequist U ed, Hagers Handbuch der pharmazeutischen Praxis, 5th edn. Berlin: Springer

Long HC (1924). Plants Poisonous to Livestock. London: Cambridge University Press. $51 \mathrm{p}$

Ma CY, Williams ID, Che CT (1999) Withanolides from Hyoscyamus niger seeds. J Nat Prod 10:1445-1447

Mack MC, D’Antonio CM (1998) Impacts of biological invasions on disturbance regimes. Trends Ecol Evol 5:195-198

Miller JS, Levin RA, Feliciano NM (2008) A tale of two continents: Baker's rule and the maintenance of self-incompatibility in Lycium (Solanaceae). Evolution 5:1052-1065 
Pimentel D, Lach L, Zuniga R, Morrison D (2000) Environmental and economic costs associated with non-indigenous species in the United States. BioScience 1:53-65

Pimentel D, Zuniga R, Morrison D (2005) Update on the environmental and economic costs associated with alieninvasive species in the United States. Ecol Econ 3:273-288

Radosevich S, Holt J, Ghersa C (2007). Weed Ecology Implications for Management. New York: Wiley. Pp 149-158

Randall R (2001) Eradication of a deliberately introduced plant found to be invasive. Page 174 in Wittenberg R \& Cock MW eds, Invasive Alien Species Toolkit of Best Prevention and Management Practices. Wallingford, Oxon, UK: CAB International

Rätsch C (1995). Heilkräuter der Antike in Ägypten, Griechenland und Rom. Mythologie und Anwendungeinst und heute. Munich: Diederichs. 419 p (Diederichsgelbe Reihe 115)

Redman RS, Kim YO, Woodward CJDA, Greer C, Espino L, Doty SL, Rodriguez RJ (2011) Increased fitness of rice plants to abiotic stress via habitat adapted symbiosis: a strategy for mitigating impacts of climate change. PLoS ONE 6:e14823

Richman AD, Kohn JR (2000) Evolutionary genetics of selfincompatibility in the Solanaceae. Plant Mol Biol 42:169-179

Rogers WE, Siemann E (2005) Herbivory tolerance and compensatory differences in native and invasive ecotypes of Chinese tallow tree (Sapium sebiferum). Plant Ecol 181:57-68

Rowell M (1978) Russian medical botany before the time of Peter the Great. Sudhoffs Archiv 62:339-358

Salisbury EJ (1942). The reproductive capacity of plants. London: Bell. Pp 133-136

Sands JM, Sands R (1976) Henbane chewing. Med J Aust 2:55-58

Selleck GW (1964) Ecology of black henbane in Saskatchewan. Weeds 12:148-150

Sharma RK, Sharma S, Sharma SS (2006) Seed germination behavior of some medicinal plants of Lahaul and Spiti cold desert (Himachal Pradesh): implications for conservation and cultivation. Curr Sci 8:1113-1118

Simberloff D (2003) How much information on population biology is needed to manage introduced species? Conserv Biol 1:83-92

Spoerke DG, Hall AH, Dodson CD, Stermitz FR, Swanson CH, Rumack BH (1987) Mystery root ingestion. J Emerg Med $5: 385-388$

Smith SD, Huxman TE, Zitzer SF, Charlet TN, Housman DC, Coleman JS, Fenstermaker LK, Seemann JR, Nowak RS (2000) Elevated $\mathrm{CO}_{2}$ increases productivity and invasive species success in an arid ecosystem. Nature 408:79-82

Stebbins GL (1957) Self fertilization and population variability in the higher plants. Am Nat 91:337-354
Stebbins GL (1974). Flowering Plants. Cambridge, MA: Belknap Press

Steinbachs JE, Holsinger KE (2002) S-RNase-mediated gametophytic self-incompatibility is ancestral in Eudicots. Mol Biol Evol 6:825-829

Suzuki RO, Kudoh H, Kachi N (2003) Spatial and temporal variations in mortality of the biennial plant, Lysimachia rubida: effects of intraspecific competition and environmental heterogeneity. J Ecol 1:114-125

[USDA] U.S. Department of Agriculture. (2015). The PLANTS Database. Greensboro, NC: National Plant Data Team, National Resources Conservation Service. http://plants.usda. gov. Accessed: April 26, 2015

[USDA] U.S. Department of Agriculture. (2016). BLM National List of Invasive Weed Species of Concern. Beltsville, MD: National Invasive Species Information Center. https:/www. invasivespeciesinfo.gov/resources/lists.shtml. Accessed: June 3, 2016

Whitson TD, Burrill LC, Dewey SA, Cudney DW, Nelson BE, Lee RD, Parker R (2004). Weeds of the West (9th edn, Newark, CA: Western Society of Weed Science, the Western United States Land Grant Universities Cooperative Extension Services, and the University of Wyoming, Jackson, WY. $628 \mathrm{p}$

Wilcove DS, Rothstein D, Dubow J, Phillips A, Losos E (1998) Quantifying threats to imperiled species in the United States. BioScience 48:607-615

Wolfe LM, Elzinga JA, Biere A (2004) Increased susceptibility to enemies following introduction in the invasive plant Silene latifolia. Ecol Lett 9:813-820

Wookey PA, Parsons AN, Welker JM, Potter JA, Callaghan TV, Lee JA, Press MC (1993) Comparative responses of phenology and reproductive development to simulated environmental change in sub-arctic and high arctic plants. Oikos 67: 490-502

Yang AF, Hamilton RI (1974) The mechanism of seed transmission of tobacco ringspot virus in soybean. Virology 62:26-37

Zorner PS, Zimdahl RL, Schweizer EE (1984) The effect of depth and duration of seed burial in kochia (Kochia scoparia). Weed Sci 32:602-607

Received March 4, 2016, and approved August 5, 2016.

Associate Editor for this paper: J. Anita Dille, Kansas State University. 